Original Article

\title{
Influence of foliar application of glycinebetaine on Tagetes erecta $L$ yield cultivated under salinity conditions
}

\author{
Influência da aplicação foliar de glicinebetaína na produtividade de Tagetes erecta L \\ cultivada em condições de salinidade
}

\author{
K. H. Alamer ${ }^{\mathrm{a} *}$ (D) and E. F. Alib,c \\ aBiological Sciences Department, Faculty of Science and Arts, King Abdulaziz University, Rabigh 21911, Saudi Arabia \\ ${ }^{\mathrm{b} B i o l o g y}$ Department, Faculty of Science, Taif University, Taif, Saudi Arabia \\ 'Department of Horticulture (Floriculture), Faculty of Agriculture, Assuit University, Assuit, Egypt
}

\begin{abstract}
Tagetes genus of Composite family consider one of the most favorite floriculture plants. Therefore, of particular interest examine the salt tolerance of this bedding and coloring agent plant. In this research, was report the role of glycinebetaine (GB) in attenuating the adverse impacts of salt stress in African marigold plant, along with their anti-oxidative capacities and biochemical attributes. The salt stressed African marigold ( 100 and $150 \mathrm{mM} \mathrm{NaCl}$ ) was treated with GB at $200 \mathrm{mM}$, beside untreated control plants. According to the obtained results, the growth characters were negatively in salt stressed plants but a mitigate impact of GB were observed in this respect. Obviously, the morphological as well as some physiological characters were reduced with salinity treatments while GB treatment reverses these effects. Overall, the alleviate impact of GB on the negative impact of salt stress was enhanced through improving total phenolic and antioxidant enzyme activity. Further, it is concluded that GB concentration induces the activities of antioxidative enzymes which scavenged ROS increased under saline conditions.
\end{abstract}

Keywords: antioxidant activity, chlorophyll, glycinebetaine, membrane stability index, salt stress.

\begin{abstract}
Resumo
O Tagetes, da família Composite, é um dos gêneros mais apreciados de plantas de floricultura. Portanto, é de particular interesse examinar a tolerância ao sal desta planta de substrato e corante. Nesta pesquisa, foi relatado o papel da glicinebetaína (GB) na atenuação dos impactos adversos do estresse salino na calêndula africana, juntamente com suas capacidades antioxidantes e atributos bioquímicos. A calêndula africana estressada com sal ( $\mathrm{NaCl} 100$ e $150 \mathrm{mM}$ ) foi tratada com GB a $200 \mathrm{mM}$, ao lado de plantas de controle não tratadas. De acordo com os resultados obtidos, os caracteres de crescimento foram negativos em plantas estressadas por sal, mas um impacto mitigado de GB foi observado neste aspecto. Obviamente, os caracteres morfológicos e fisiológicos foram reduzidos com os tratamentos de salinidade, enquanto o tratamento com GB reverteu esses efeitos. No geral, o impacto de alívio do GB no impacto negativo do estresse salino foi aprimorado através da melhoria da atividade das enzimas fenólicas e antioxidantes totais. Além disso, conclui-se que a concentração de GB induz as atividades de enzimas antioxidantes que sequestraram ROS aumentadas em condições salinas.
\end{abstract}

Palavras-chave: atividade antioxidante, clorofila, glicinabetaína, índice de estabilidade de membrana, estresse salino.

\section{Introduction}

Tagetes erecta $\mathrm{L}$. is an herbaceous plant contains small leaves and flowers in comparison to other marigolds. Moreover, African marigold is a valuable crop for controlling parasitic nematodes (Dole and Wilkins, 2005). The essential oils in addition to lutein (carotenoids), which used in the food supplements, manufacture of soap, perfumes, cosmetics, and pharmaceutical industries were extracted from the aerial parts (Šivel et al., 2014).
Soil salinization and water irrigation in Saudi Arabia lands (arid and semi-arid areas) causes a serious abiotic stress including degradation of agricultural lands, especially that controlling the growth and yield (Hassan and Ali, 2014). Further, salt stress changes an imbalance in the cytosolic ionic flow of cells and thus results in oxidative damage that affects the function of the lipid bilayer and the photosynthetic rate as well as the metabolism of cells

*e-mail: kalamer@kau.edu.sa

Received: September 19, 2021 - Accepted: January 18, 2022 
(Suzuki et al., 2016). Salinity decreased the productivity in numerous medicinal plants (Ali and Hassan, 2014; Attia et al., 2020), and induces oxidative stress via increased ROS production which is related to tissue destruction (Bernstein et al., 2010). The two defense mechanisms against salt were detoxify ROS by stimulating ROS scavenger enzymes like catalases, superoxides dismutase and peroxidases activities (Abdel Latef and Chaoxing, 2011) and /or non-enzymatic antioxidants, i.e. osmoregulation $\mathrm{GB}$, ascorbate, phenolics, tocopherol, reduced glutathione, and proline (Mansour and Salama, 2019).

Chen and Murata (2008) (reported that GB is a compatible solute, water-soluble and non-toxic at elevated levels has the roles of effective protection of plant cells against salinity stress through osmotic stress adjustment (Liang et al., 2009), protein stabilisation (Rubisco) (Hamani et al., 2020), protection of the photosynthetic machinery (Tian et al., 2017), and decrease of oxygen radical scavengers (Wei et al., 2017). Glycinebetaine accumulation in salt tolerant and salt sensitive lines of rice was stimulated by early salt exposure (Cha-um et al., 2007). These authors reported that in salt-tolerant rice seedlings, the accumulation of GB immediately after initial exposure to salt stress may be useful in stabilizing the photosynthetic machinery leading to improved growth efficiency.

Tagetes erecta, currently known as tagetes/souci, has flowers of different colours (orange, yellow, mixed) and a bitter flavour resembling cloves (Mlcek and Rop, 2011) Marigold is an important ornamental plant from the family Compositae which is currently in environmental management and also evaluated as a flower cut (Riaz et al., 2013). Tagetes species are largely well documented for their flavonoid and terpene content (Munhoz et al., 2014). In consequence, they are reported to have antimicrobial (Gakuubi et al., 2016), insecticidal (Fabrick et al., 2020), larvicidal (Giarratana et al., 2017) and antioxidant (Sadique et al., 2021) properties and are used as traditional medicines in different countries as a treatment for colic, diarrhea, vomiting, fever, skin diseases and liver disorders (Jain et al., 2012). Among the ornamental flowering plants, marigold is reported to grow well in saline conditions (Escalona et al., 2012). A number of marigold cultivars used as flowering cuttings or as ornamental bedding plants in landscaping may be grown with maintained plant quality under salt stress with an ECw $\leq 8 \mathrm{dS}^{-1}$ (Valdez-Aguilar et al., 2009). The tolerance to salinity of various ornamental plants used in landscaping is not well-known. In zones with problems of salinity, there is not sufficient information for environmental planners and ornamental plant producers to suggest adequate plant species. Thus, the object of this work was to investigate the impact of GB application on plant development, productivity and quality of cultivated marigold flowers grown in saline conditions, highlighting carotenoids production (lutein) as an important product for flowering of this plant.

\section{Materials and Methods}

\subsection{Experimental set-up}

A potted greenhouse experiment was conducted at Taif University, Saudi Arabia through the seasons 2018 - 2019. Plant seeds were soaked in an aerated solution of $\mathrm{CaSO}_{4}$, $1 \mathrm{mM}$ for 1 day and then germinated in darkness at $28^{\circ} \mathrm{C}$ for 2 days between two layers of filter paper. After 4 days, the seedlings were placed in the soil in $25 \mathrm{~cm}$ size pots. Physical characteristics of the soils were (sand, $77.21 \%$, silt $7.99 \%$, clay $14.80 \%$ ) and the chemical soil properties were ( $\mathrm{pH} 7.98$, EC $2.65 \mathrm{dSm}^{-1}, \mathrm{OM} 0.14 \%, \mathrm{Na}^{+} 3.12, \mathrm{SO}_{4}^{-2} 43.25, \mathrm{HCO}_{3} 2.75$ and $\mathrm{Cl}^{-} 0.42$ meqL $\mathrm{L}^{-1}$, total $\mathrm{N}^{+} 0.15 \%$ and $\mathrm{PO}_{4}{ }^{3-} 0.037 \%$ ). Pots were placed in a growth chamber charged with a NPK mineral fertilizer (17:17:17) at $5 \mathrm{~g}$ per pot and at a temperature of $26^{\circ} \mathrm{C} / 18^{\circ} \mathrm{C}$ in light $\left(200 \mathrm{~W} \mathrm{~m}^{-2}\right)$ and dark period, respectively with relative humidity at $70 \%$. Irrigation at intervals of 2 days was applied to the plant. After the fourth true leaves appeared (21 days after planting), $\mathrm{NaCl}$ levels were gradually increased to 100 and $150 \mathrm{mM}$ with or without $200 \mathrm{mM} \mathrm{GB}$ (Joushan et al., 2020) as foliar application. Glycinebetaine treatments were applied three-months after transplanting and for three times every 15 days. The shoots were sprayed until the drop of the spray solution.

\subsection{Growth and flower characters}

Shoot length in $\mathrm{cm}$, branch number per plant, shoot and root fresh and dry weights (g/plant), flower number plant $^{-1}$ and flower weight per plant (fresh and dry) taken in this experiment. Leaf number/plant and its area $\left(\mathrm{cm}^{2}\right)$ were followed, leaf blade areas were established by a digital picture analysis as reported by O'Neal et al. (2002).

\subsection{Chlorophyll and carotenoid assessment}

Chlorophyll was determined as described by Shabala et al. (1998) utilizing the following equation: Chl $=12.7$ A663 - 2.63 A645 with A663 and A645, the absorbance measured with UV/visible spectrophotometer (Beckman DU 640, USA) at 663 and 645, respectively. While total carotenoid concentrations $(\mathrm{CX}+\mathrm{c})$ were estimated by methods of Lichtenthaler (1987).

\subsection{Relative water content ( $R W C$ )}

Methods of Weatherley (1950) were applied to measure Relative Water Content on the basis of the equations: (FW-DW) / (TW-DW) x 100, in which FW: fresh weight, TW: turgid weight when saturated with distilled water for 24 h at $4{ }^{\circ} \mathrm{C}$, and DW: dry weight.

\subsection{Membrane stability index (MSI)}

Samples of leaves were collected from mid-plant for determining the ion leakage as reported by Sairam et al. (1997). Leaf samples were washed with deionized water to remove the adhered particles. The leaves were then cut into small disks of uniform size and placed in closed test tubes containing $10 \mathrm{~mL}$ of deionized water. The tubes containing leaf samples were then incubated at $25^{\circ} \mathrm{C}$ for $24 \mathrm{~h}$ and subsequently electrical conductivity (EC) of the 
solution (C1) was recorded using an Acromet AR20 electrical conductivity meter (Fisher Scientific, Chicago, IL). The samples were then autoclaved at $120{ }^{\circ} \mathrm{C}$ for $20 \mathrm{~min}$ and the final EC (C2) was recorded after equilibrium at $25^{\circ} \mathrm{C}$. The ion leakage was determined as Membrane Stability Index according to the formula: $\mathrm{MSI}=\left(1-\left(\mathrm{C}_{1} / \mathrm{C}_{2}\right)\right) \times 100$.

\subsection{Total phenolics}

Leaf powdered samples ( $1 \mathrm{~g}$ ) were extracted in $80 \%$ methanol and assaying the total phenolics using Folin-Ciocalteu reagent as described by McDonald et al. (2001), expressed as g GAE kg-1 DW.

\subsection{Anti-oxidation enzymes assays}

The determination of the anti-oxidant enzymes SOD, CAT and POX assay in leaf extract and the soluble protein levels were analyzed by Bradford's (1976) method.

The activity of SOD (EC 1.15.1.1) was estimated by the determination of its capacity to inhibit photo-chemical degradation of tetrazolium nitroblue (NBT) as reported by Giannopolitis and Ries (1977).

The activity of CAT (EC 1.11.1.6) was measured spectrophotometrically according to Clairbone (1985).

The activity of POX (EC 1.11.1.7) was assayed as described by Shannon et al. (1966).

The expression of enzymatic activities was given in

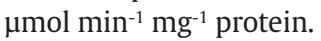

\subsection{Potassium and sodium contents}

Dried marigold leaf was wet digested to estimate potassium and sodium content as mentioned by Jackson (1978).

\subsection{Statistical analysis}

Experiments were carried out twice in four replicates and the ANOVA will be performed with the program MSTAT. Means were separated using Duncan's multiple range tests at a significance level of 0.05 .

\section{Results and Discussion}

\subsection{Effect of $\mathrm{NaCl}$ stress and $\mathrm{GB}$ on growth and nutritional status of T. erecta}

Analysis of variance (ANOVA) for the data on vegetative characters: height of plant, number of branch, number of secondary branch, FW and DW (g/plant) of African marigold shoot and root showed that salinity stress treatments ( 100 and $150 \mathrm{mM} \mathrm{NaCl}$ ) significantly reduced these parameters (Table 1 ). The reduce in leaf number and leaf area was the response to the effect of salinity, described similar outcomes (Table 1). While, when GB at $200 \mathrm{mM}$ was applied exogenously, an improvement and enhancing of the previous parameters.

Similarly, flower attributes; i.e. flower number per plant, fresh and dry flower weight (g/flower) sharply reduced by salinity, while the application of $200 \mathrm{mM} \mathrm{GB}$ improved it especially at $100 \mathrm{mM} \mathrm{NaCl}$ (Table 1). Our findings are in agreement with Kausar et al. (2014) who showed that external application of glycinebetaine enhanced fresh and dry weight of maize roots and shoots under salt stress. The injure impacts of salinity causes disturbance in some metabolic, reduction of net photosynthesis, decline in water availability, imbalance of ionic, enlargement inhibition of cell or impairment of meristematic activity (Abdul Qados,

Table 1. Effect of $\mathrm{NaCl}$ stress and glycinebetaine on biomass indicators and leaf sodium and potassium content of Tagetes erecta $\mathrm{L}$.

\begin{tabular}{|c|c|c|c|c|c|}
\hline Treatments & Control & $\mathrm{NaCl}, 100 \mathrm{mM}$ & $\mathrm{NaCl}, 150 \mathrm{mM}$ & $\begin{array}{c}\mathrm{NaCl}, 100 \mathrm{mM} \\
+ \\
\mathrm{GB}, 200 \mathrm{mM}\end{array}$ & $\begin{array}{c}\mathrm{NaCl}, 150 \mathrm{mM} \\
+ \\
\mathrm{GB}, 200 \mathrm{mM}\end{array}$ \\
\hline \multicolumn{6}{|l|}{ Parameters } \\
\hline Plant height, $\mathrm{cm}$ & $65.56 \pm 2.599^{a}$ & $52.87 \pm 2.3^{c}$ & $48.68 \pm 3.14 b$ & $54.69 \pm 2.15 \mathrm{bc}$ & $50.67 \pm 3.65 b c$ \\
\hline Main branch, number.plant ${ }^{-1}$ & $8.24 \pm 0.29^{a}$ & $6.25 \pm 0.34^{b}$ & $4.98 \pm 0.28^{c}$ & $7.99 \pm 0.39$ a & $6.85 \pm 0.43^{b}$ \\
\hline Secondary branch, number.plant ${ }^{-1}$ & $25.02 \pm 1.23^{a}$ & $16.25 \pm 1.36^{c}$ & $15.12 \pm 2.04^{\mathrm{d}}$ & $20.54 \pm 1.58^{b}$ & $19.92 \pm 2.06 \mathrm{~b}$ \\
\hline Leaf number, plant ${ }^{-1}$ & $280.25 \pm 6.25^{a}$ & $221.36 \pm 5.32^{c}$ & $198.57 \pm 3.98^{d}$ & $279.98 \pm 4.85^{a}$ & $242.15 \pm 5.85^{b}$ \\
\hline Leaf area, $\mathrm{cm}^{2}$ & $2.71 \pm 0.066^{a}$ & $1.87 \pm 0.07^{c}$ & $1.63 \pm 0.06^{\mathrm{d}}$ & $2.64 \pm 0.08$ & $2.23 \pm 0.05^{b}$ \\
\hline Flower numbers, plant ${ }^{-1}$ & $7.92 \pm 0.21$ & $5.02 \pm 0.15^{c}$ & $3.24 \pm 0.23^{d}$ & $7.98 \pm 0.31^{a}$ & $6.87 \pm 0.24^{b}$ \\
\hline Root FW, g.plant ${ }^{-1}$ & $9.36 \pm 0.14^{\mathrm{a}}$ & $5.89 \pm 0.12^{d}$ & $5.12 \pm 0.26^{\mathrm{d}}$ & $7.36 \pm 0.31^{b}$ & $6.99 \pm 0.37^{b}$ \\
\hline Root DW, g.plant ${ }^{-1}$ & $3.21 \pm 0.08^{a}$ & $2.12 \pm 0.07^{c}$ & $1.89 \pm 0.09^{d}$ & $2.86 \pm 0.04^{b}$ & $2.54 \pm 0.06^{c}$ \\
\hline Shoot FW, g.plant ${ }^{-1}$ & $154.56 \pm 5.06{ }^{a}$ & $122.47 \pm 6.25^{\mathrm{d}}$ & $119.14 \pm 4.69$ e & $136.58 \pm 8.69 b$ & $133.56 \pm 7.36{ }^{c}$ \\
\hline Shoot DW, g.plant ${ }^{-1}$ & $39.25 \pm 1.41^{a}$ & $26.05 \pm 2.36^{d}$ & $28.69 \pm 1.89 c$ & $29.58 \pm 1.27^{b}$ & $28.69 \pm 1.89^{c}$ \\
\hline Flower FW, g.flower-1 & $7.72 \pm 0.28{ }^{a}$ & $5.25 \pm 0.43^{c}$ & $4.47 \pm 0.42^{\mathrm{d}}$ & $7.04 \pm 0.36^{a}$ & $6.04 \pm 0.39^{b}$ \\
\hline Flower DW, g.flower ${ }^{-1}$ & $2.08 \pm 0.06^{b}$ & $1.56 \pm 0.05^{\mathrm{d}}$ & $1.24 \pm 0.04 \mathrm{e}$ & $2.98 \pm 0.03 \mathrm{a}$ & $1.86 \pm 0.07^{c}$ \\
\hline $\mathrm{Na}^{+}, \mathrm{mg} \cdot \mathrm{g}^{-1} \mathrm{DW}$ & $2.31 \pm 0.08 \mathrm{e}$ & $3.24 \pm 0.07^{b}$ & $4.52 \pm 0.06^{\mathrm{a}}$ & $2.63 \pm 0.05^{\mathrm{d}}$ & $2.76 \pm 0.08^{c}$ \\
\hline $\mathrm{K}^{+}, \mathrm{mg} \cdot \mathrm{g}^{-1} \mathrm{DW}$ & $2.34 \pm 0.07 \mathrm{a}$ & $2.26 \pm 0.08^{b}$ & $2.21 \pm 0.06^{c}$ & $2.33 \pm 0.07 \mathrm{a}$ & $2.38 \pm 0.09 a^{a}$ \\
\hline
\end{tabular}

Sodium and potassium are the mean of six replicates. All the other parameters are means \pm S.D $(n=14)$. The means with the different letters are statistically different from the others based on Duncan's multiple range test at $P=0.05$. 
2015). Same results have already been mentioned by Ali and Hassan (2014) on Chamomile, and Mansour and Ali (2017) on Calendula officinalis L. Salinity decreases the osmotic potential of the soil solution and consequently reduces water uptake by the roots; cell turgidity is lowered leading to plasmolysis (Verslues et al., 2006). Some plants regulate their internal osmotic pressure by the synthesis of osmoprotectants, mainly soluble sugars and amino acids such as proline and glycinebetaine (Wani et al., 2013). Parvin et al. (2015) mentioned that, GB application was enhanced leaf numbers and reduced salinity. Glycinebetaine will reduce the effect of stress on the plant on the one hand, and provide a source of nitrogen and energy to the plant on the other. Proline and glycinebetaine improve the growth of cereals in the presence of various abiotic stresses (Ashraf and Foolad, 2007). Tagetes plants had a higher leaf $\mathrm{Na}$ concentration with the high $\mathrm{NaCl}$ concentration (150 $\mathrm{mM}$ ) accompanied by a decrease in potassium supply. GB spraying significantly decreased $\mathrm{Na}^{+}$levels while increasing potassium levels. Recently, Attia et al. (2020) recorded a decrease in damask rose by salt stress treatments may be due to nutrition imbalance statues and $\mathrm{K}, \mathrm{Ca}$ and $\mathrm{Mg}$ reduction in the photosynthetic organs.

\subsection{Effect of $\mathrm{NaCl}$ stress and $\mathrm{GB}$ on membrane stability index (MSI) and relative water content (RWC) of T. erecta leaves}

Figure 1 shows the membrane stability index (MSI) and relative water content (RWC) in leaves of Tagetes plants grown in the absence or presence of $\mathrm{NaCl}$ and sprayed with GB. Generally, the MSI (\%) reduced as the $\mathrm{NaCl}$ level was higher. Tagetes plants stressed with $\mathrm{NaCl}$ had 25-30\% lower MSI than those not stressed, at 100 and $150 \mathrm{mM}$ $\mathrm{NaCl}$, respectively. The negative impact of high $\mathrm{NaCl}$ was mitigated by treating $\mathrm{NaCl}$-stressed plants with $\mathrm{GB}$; in fact, GB (200 mM) further increased MSI. RWC exhibited similar results to MSI with exposure of Tagetes plants to $\mathrm{NaCl}$ stress resulting in a significant reduction in RWC. Thus, the RWC values are 75 and $70 \%$ at 100 and $150 \mathrm{mM}$ $\mathrm{NaCl}$, respectively. GB enhanced RWC in Tagetes leaves in the presence of $\mathrm{NaCl}$. $\mathrm{NaCl}$ stress not only reduces the

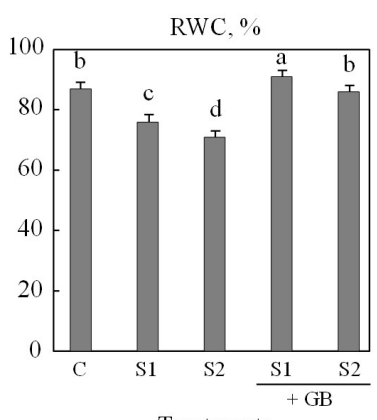

Treatments

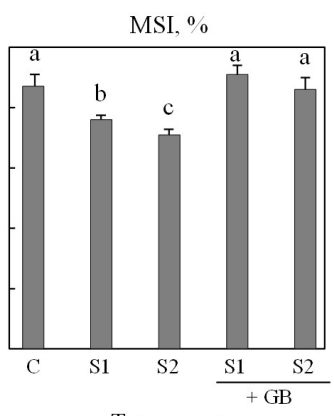

Treatments
Figure 1. Effect of $\mathrm{NaCl}$ stress and glycinebetaine on relative water content (RWC) and membrane stability index (MSI) in Tagetes erecta L leaves. $\mathrm{C}=$ control; $\mathrm{S} 1=\mathrm{NaCl}, 100 \mathrm{mM} ; \mathrm{S} 2=\mathrm{NaCl}, 150 \mathrm{mM} ; \mathrm{GB}=$ Glycinebetaine, $200 \mathrm{mM}$. Values are means $\pm \operatorname{S.D}(n=6)$. The means with the different letters are statistically different from the others based on Duncan's multiple range test at $P=0.05$. growth and productivity dynamics of African marigold, but also affects MSI and RWC. Comparable results have already been reported for common bean (Bayuelo-Jiménez et al., 2012). The adverse effect of $\mathrm{NaCl}$ on African marigold plants is mainly due to the high osmotic stress and ionic toxicity that results from long-term exposure to high levels of $\mathrm{NaCl}$. Osmotic stress leads to water deficit and decreased nutrient uptake by plant roots in immediate feedback to the high osmolarity of the soil solution (El-Ramady et al., 2019). In addition, ion toxicity resulting from the high $\mathrm{Na}^{+}$and $\mathrm{Cl}^{-}$accumulation in plant tissues induces early senescence. As a result, further impairment of plant development, cell division, elongation of cells, synthesis of proteins and the process of photosynthesis occurs in parallel with the rapid generation of ROS (El-Ramady et al., 2018). Glycinebetaine foliar application can enhance abiotic constraint tolerance of several plants and subsequently improve growth and productivity, so if applied to photosynthetic organs, it is well absorbed by foliar tissues localized in cytosol and translocate to chloroplasts (Kausar et al., 2014) and also taken up via roots (Hameed et al., 2010).

\subsection{Effect of $\mathrm{NaCl}$ stress and $\mathrm{GB}$ on pigment content of T. erecta}

Pigment data for total chlorophylls and carotenoids from $T$. erecta plants spray-treated with GB in the presence of high concentrations of $\mathrm{NaCl}$ were illustrated in Figure 2. We found that, in general, all chlorophyll pigment levels decreased when the plants were supplied with $\mathrm{NaCl}$. Increasing the $\mathrm{NaCl}$ concentration resulted in a significant reduction in carotenoid levels. However, treatment of plants with GB by foliar application induced plant growth causing an increase in the content of these pigments. The highest increase was observed especially for carotenoids. Thus, the values recorded in plants grown in the presence of $100 \mathrm{mM} \mathrm{NaCl}$ and treated with GB are comparable to those of the control plants. Due to a disturbance in growth processes, hydration and potassium nutrition in T. erecta plants grown under $\mathrm{NaCl}$ stress, the photosynthetic process and its efficiency will be imperatively damaged and affected. Our present results are in agreement with this approach. It is well documented that plant species sensitive to salt are more affected by the negative effects
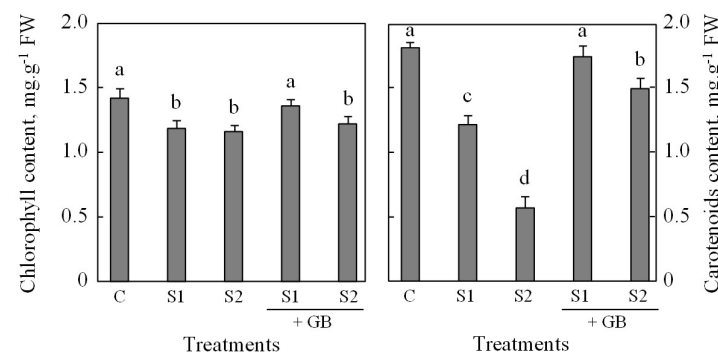

Figure 2. Effect of $\mathrm{NaCl}$ stress and glycinebetaine on chlorophyll and carotenoids contents in Tagetes erecta $\mathrm{L}$ leaves. $\mathrm{C}=$ control; $\mathrm{S} 1=\mathrm{NaCl}, 100 \mathrm{mM} ; \mathrm{S} 2=\mathrm{NaCl}, 150 \mathrm{mM} ; \mathrm{GB}=$ Glycinebetaine, 200 $\mathrm{mM}$. Values are means \pm S.D $(n=6)$. The means with the different letters are statistically different from the others based on Duncan's multiple range test at $P=0.05$. 
of salinity which leads to a decrease in chlorophyll levels (Attia et al., 2020). The decrease in photosynthetic pigments might be the consequence of a malfunction in their biosynthesis under salt stress (Attia et al., 2011). However, GB exhibited significant potential to improve photosynthetic pigment biosynthesis under salinity stress in mustard (Islam et al., 2021). Furthermore, beneficial effects of exogenous GB on net photosynthesis, stomatal conductance and the Photosystem II (PSII) efficiency have already been documented by Alasvandyaria and Mahdavia (2018) in salt-stressed safflower plants. Hoque et al. (2007) revealed that GB has an important role in protecting the photosynthetic machinery by maintaining protein reparation activity under salinity stress.

\subsection{Effect of $\mathrm{NaCl}$ stress and $\mathrm{GB}$ on phenolics compounds of $T$. erecta leaves}

In the light of the results of Polyphenol contents reported in Figure 3, it appears that $T$. erecta is poor in these compounds. These leaf contents increased with the concentration of $\mathrm{NaCl}$ in the medium. The GB treatment further enhanced these contents, which achieved much higher values than the control or salt-stressed plants. The mechanisms which protect membranes against excessive lipid peroxidation appear to differ according to the nature of the stress and the organ, and may be coupled with an increase in phenol accumulation or the activity of peroxidase (Tokarz et al., 2020). Most probably, phenols

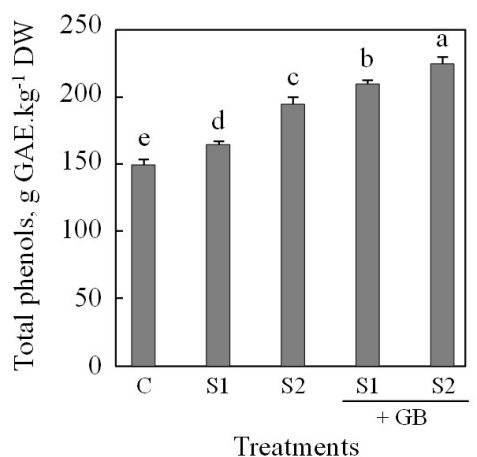

Figure 3. Effect of $\mathrm{NaCl}$ stress and glycinebetaine on total phenols content in Tagetes erecta L leaves. $\mathrm{C}=$ control; $\mathrm{S} 1=\mathrm{NaCl}, 100 \mathrm{mM}$; $\mathrm{S} 2=\mathrm{NaCl}, 150 \mathrm{mM} ; \mathrm{GB}=$ Glycinebetaine, $200 \mathrm{mM}$. Values are means \pm S.D $(n=6)$. The means with the different letters are statistically different from the others based on Duncan's multiple range test at $P=0.05$. were involved in sodium chelation especially in the cell wall (Tokarz et al., 2020). A comparable elevation of phenols in NaCl-treated plants, compared to the control, suggested that phenolic compounds in $T$. erecta leaves functioned as osmoprotectors. It was reported previously that with salinity, a significant positive influence of exogenous glycinebetaine application on plant growth and secondary metabolite accumulation was observed. Furthermore, many researchers have reported that glycinebetaine has positive responses to salt stress in several plants such as ryegrass (Hu et al., 2012) and safflower (Kim et al., 2021). Our present results, in which the application of exogenous betaine affected the accumulation of phenolic compounds in marigold leaves, are in agreement with these. GB enhances the metabolism of phenolic compounds. Therefore, it is reasonable to conclude that the improvement of phenolics by GB treatment might be playing a beneficial role in the scavenging of reactive oxygen species, which help to protect the cell membrane from peroxidation and damage.

\subsection{Effect of $\mathrm{NaCl}$ stress and $\mathrm{GB}$ on anti-oxidation enzymes of $T$. erecta leaves}

Activity of all studied enzymes, CAT, POX and SOD, in marigold leaves decreased with increasing $\mathrm{NaCl}$ treatments (Table 2). The antioxidant activities increased significantly when applying GB treatment, which resulted in increased scavenging activity, which had an important protective role on the growth of African marigold and improved the ability of its leaves to photosynthesize against salt stress (Islam et al., 2021). Improving the systems of antioxidant defense in response GB treatment was scavenged ROS and enhanced the stability of membrane (Nahar et al., 2016). GB are able to proteins stabilizer, lipids of membrane, structures of cell, cell turgor maintenance, adjustment of osmotic pressure, nitrogen storage, and redox metabolism to ROS scavenging under salinity (Liang et al., 2009). Finally, the amino acid derivative $G B$ is protective of higher plants from salt and osmotic stress in various ways: through osmotic adjustment (Liang et al., 2009), oxygen releasing stabilizer PS-II (Huang et al., 2020), membranes and protein quaternary structures (Tian et al., 2017), and the enzymes RUBISCO (Hamani et al., 2020). Glycinebetaine play a major role in protein synthesis, maintaining the association between tRNA and the ribosome during translation (Flowers and Colmer, 2008). The presence of such molecules allows a wide variety of living organisms to withstand extreme conditions such as temperature variations and high salinity (Smiatek et al., 2012), and

Table 2. Effect of $\mathrm{NaCl}$ stress and glycinebetaine on antioxidant enzymes (unit $\mathrm{mg}^{-1}$ protein) in Tagetes erecta $\mathrm{L}$ leaves.

\begin{tabular}{|c|c|c|c|c|c|}
\hline Treatments & Control & $\mathrm{NaCl}, 100 \mathrm{mM}$ & $\mathrm{NaCl}, 150 \mathrm{mM}$ & $\begin{array}{c}\mathrm{NaCl}, 100 \mathrm{mM} \\
+ \\
\mathrm{GB}, 200 \mathrm{mM}\end{array}$ & $\begin{array}{c}\mathrm{NaCl}, 150 \mathrm{mM} \\
+ \\
\mathrm{GB}, 200 \mathrm{mM}\end{array}$ \\
\hline SOD & $2.37 \pm 0.14^{\mathrm{a}}$ & $1.74 \pm 0.16^{c}$ & $1.91 \pm 0.12^{\mathrm{b}}$ & $2.34 \pm 0.099^{a}$ & $2.35 \pm 0.10^{a}$ \\
\hline CAT & $2.43 \pm 0.06^{\mathrm{a}}$ & $1.61 \pm 0.08^{d}$ & $1.82 \pm 0.06^{c}$ & $2.37 \pm 0.04^{b}$ & $2.42 \pm 0.05^{\mathrm{a}}$ \\
\hline POX & $24.12 \pm 1.09 \mathrm{a}$ & $16.08 \pm 1.21^{\mathrm{d}}$ & $18.57 \pm 1.57^{c}$ & $22.18 \pm 1.26^{b}$ & $23.86 \pm 1.21^{a}$ \\
\hline
\end{tabular}

Values are means \pm S.D $(n=6)$. The means with the different letters are statistically different from the others based on Duncan's multiple range test at $P=0.05$. SOD = superoxide dismutase; $C A T=$ catalase; $P O X=$ guaiacol peroxidase. 
they play an essential role in stabilizing proteins and membranes during oxidative damage induced by ROS (Saxena et al., 2013).

\section{Conclusion}

Based on the obtained findings, a conclusion can be drawn the growth and flowering characters were significantly decreased by salt stress treatments, while GB application promoted the growth as well as flowering attributes in stressed plants. In the same context, RWC, MSI, pigments content and phenolics content were also improved due to GB treatment. Accordingly, the oxidative stress decreased and salt stress inhibitory impacts on African marigold were reduced as a result of GB treatment. This indicates that GB not only nullified the impact of salt stress, but also significantly improved growth, physio-biochemical parameters in addition to changes non-enzymatic and enzymatic antioxidants activities in plants of African marigold.

\section{Acknowledgements}

This project was funded by the Deanship of Scientific Research (DSR) at King Abdulaziz University, Jeddah, under grant no. (G: 318-662-1441). The authors, therefore, acknowledge with thanks DSR for technical and financial support.

\section{References}

ABDEL LATEF, A.A. and CHAOXING, H., 2011. Effect of arbuscular mycorrhizal fungi on growth, mineral nutrition, antioxidant enzymes activity and fruit yield of tomato grown under salinity stress. Scientia Horticulturae, vol. 127, no. 3, pp. 228-233. http:// dx.doi.org/10.1016/j.scienta.2010.09.020.

ABDUL QADOS, A.M.S., 2015. Effects of salicylic acid on growth, yield and chemical contents of pepper (Capsicum annuum L) plants grown under salt stress conditions. International Journal of Agriculture and Crop Sciences, vol. 8, pp. 107-113.

ALASVANDYARIA, F. and MAHDAVIA, B., 2018. Effect of glycine betaine and salinity on photosynthetic pigments and ion concentration of safflower. Desert, vol. 23, no. 2, pp. 265-271.

ALI, E.F. and HASSAN, F., 2014. Alleviatory effects of salt stress by mycorrhizal fungi and gibberellic acid on chamomile plant. International Journal of Scientific Research, vol. 3, no. 11, pp. 109-118.

ASHRAF, M. and FOOLAD, M.R., 2007. Roles of glycine betaine and proline in improving plant abiotic stress resistance. Environmental and Experimental Botany, vol. 59, no. 2, pp. 206-216. http://dx.doi.org/10.1016/j.envexpbot.2005.12.006.

ATTIA, H., AL-YASI, H., ALAMER, K., ALI, E., HASSAN, F., ELSHAZLY, S. and HESSINI, K., 2020. Induced anti-oxidation efficiency and others by salt stress in Rosa damascena Miller. Scientia Horticulturae, vol. 274, pp. 109681. http://dx.doi.org/10.1016/j. scienta.2020.109681.

ATTIA, H., OUHIBI, C., ELLILI, A., MSILINI, N., BOUZAÏEN, G., KARRAY, N. and LACHAÂL, M., 2011. Analysis of salinity effects on basil leaf surface area, photosynthetic activity, and growth. Acta
Physiologiae Plantarum, vol. 33, no. 3, pp. 823-833. http:// dx.doi.org/10.1007/s11738-010-0607-6.

BAYUELO-JIMÉNEZ, J.S., JASSO-PLATA, N. and OCHOA, I., 2012. Growth and physiological responses of Phaseolus species to salinity stress. International Journal of Agronomy, vol. 2012, pp. 13. http://dx.doi.org/10.1155/2012/527673.

BERNSTEIN, N., SHORESH, M., XU, Y. and HUANG, B., 2010. Involvement of the plant antioxidative response in the differential growth sensitivity to salinity of leaves vs. roots during cell development. Free Radical Biology \& Medicine, vol. 49, no. 7, pp. 1161-1171. http://dx.doi.org/10.1016/j. freeradbiomed.2010.06.032. PMid:20619339.

BRADFORD, M.M., 1976. A rapid and sensitive method for quantitation of micro quantities of protein utilizing the principle of protein-dye binding. Analytical Biochemistry, vol. 72, no. 1-2, pp. 248-254. http://dx.doi.org/10.1016/0003-2697(76)905273. PMid:942051.

CHA-UM, S., SUPAIBULWATANA, K. and KIRDMANEE, C., 2007. Glycinebetaine accumulation, physiological characterizations, and growth efficiency in salt tolerant and salt sensitive lines of indica rice (Oryza sativa L. ssp. indica) response to salt stress. Journal Agronomy E' Crop Science, vol. 193, no. 3, pp. 157-166. http://dx.doi.org/10.1111/j.1439-037X.2007.00251.x.

CHEN, T.H.H. and MURATA, N., 2008. Glycinebetaine: an effective protectant against abiotic stress in plants. Trends in Plant Science, vol. 13, no. 9, pp. 499-505. http://dx.doi.org/10.1016/j. tplants.2008.06.007. PMid:18703379.

CLAIRBONE, A., 1985. Catalase activity. In: R. GREENWALD, ed. Handbook of methods for oxygen radical research. Boca Raton: CRC Press, pp. 283-284.

DOLE, J.M. and WILKINS, H.F., 2005. Floriculture principles and species. USA: Prentice-Hall, $1023 \mathrm{p}$.

EL-RAMADY, H., ALSHAAL, T., BAKR, N., ELBANA, T., MOHAMED, E. and BELAL, A.A., 2019. Soils of egypt. 1st ed. Cham: Springer. (World Soils Book Series).

EL-RAMADY, H., ALSHAAL, T., ELHAWAT, N., GHAZI, A., ELSAKHAWY, T., OMARA, A.E.D., ELNAHRAWY, S., ELMAHROUK, M., ABDALLA, N., DOMOKOS-SZABOLCSY, É. and SCHNUG, E., 2018. Plant nutrients and their roles under saline soil conditions. In: M. HASANUZZAMAN, ed. Plant nutrients and abiotic stress tolerance. Singapore: Springer, pp. 297-324. http://dx.doi.org/10.1007/978981-10-9044-8_13.

ESCALONA, A., VALVERDE, J., SANTOS, C.C. and SALAS, M.C., 2012. Preliminary study of the response of ornamental plants to the $\mathrm{NaCl}$ case 1. Tagetes erecta L. Acta Horticulturae, no. 937, pp. 955-962. http://dx.doi.org/10.17660/ActaHortic.2012.937.118.

FABRICK, J.A., YOOL, A.J. and SPURGEON, D.W., 2020. Insecticidal activity of marigold Tagetes patula plants and foliar extracts against the hemipteran pests, Lygus hesperus and Bemisia tabaci. PLoS One, vol. 19, no. 5, e0233511. PMid:32428032.

FLOWERS, T.J. and COLMER, T.D., 2008. Salinity tolerance in halophytes. The New Phytologist, vol. 179, no. 4, pp. 945963. http://dx.doi.org/10.1111/j.1469-8137.2008.02531.x. PMid: 18565144.

GAKUUBI, M.M., WANZALA, W., WAGACHA, J.M. and DOSSAJI, S.F., 2016. Bioactive properties of Tagetes minuta L. (Asteraceae) essential oils: a review. American. Journal of Essential Oils and Natural Products, vol. 4, pp. 27-36.

GIANNOPOLITIS, C.N. and RIES, S.K., 1977. Superoxide dismutase I. Occurrence in higher plants. Plant Physiology, vol. 59, no. 2, pp. 309-314. http://dx.doi.org/10.1104/pp.59.2.309. PMid:16659839.

GIARRATANA, F., MUSCOLINO, D., ZIINO, G., GIUFFRIDA, A., MAROTTA, S.M., LO PRESTI, V., CHIOFALO, V. and PANEBIANCO, A., 
2017. Activity of Tagetes minuta Linnaeus (Asteraceae) essential oil against L3 Anisakis larvae type 1. Asian Pacific Journal of Tropical Medicine, vol. 10, no. 5, pp. 461-465. http://dx.doi. org/10.1016/j.apjtm.2017.05.005. PMid:28647183.

HAMANI, A.K.M., WANG, G., SOOTHAR, M.K., SHEN, X., GAO, Y., QIU, R. and MEHMOOD, F., 2020. Responses of leaf gas exchange attributes, photosynthetic pigments and antioxidant enzymes in $\mathrm{NaCl}$-stressed cotton (Gossypium hirsutum L.) seedlings to exogenous glycine betaine and salicylic acid. BMC Plant Biology, vol. 20, no. 1, pp. 434. http://dx.doi.org/10.1186/s12870-02002624-9. PMid:32957907.

HAMEED, M., ASHRAF, M., AHMAD, M.S.A.L. and NAZ, N., 2010 Structural and functional adaptations in plants for salinity tolerance. In: M. ASHRAF, M. OZTURK and M.S.A. AHMAD, eds. Plant adaptation and phytoremediation. Dordrecht: Springer, pp. 151-170. http://dx.doi.org/10.1007/978-90-481-9370-7_8.

HASSAN, F. and ALI, E., 2014. Effects of salt stress on growth, antioxidant enzyme activity and some other physiological parameters in jojoba [Simmondsia chinensis (Link) Schneider] plant. Australian Journal of Crop Science, vol. 8, pp. 1615-1624.

HOQUE, M.A., BANU, M.N.A., OKUMA, E., AMAKO, K., NAKAMURA, Y., SHIMOISHI, Y. and MURATA, Y., 2007. Exogenous proline and glycinebetaine increase $\mathrm{NaCl}$-induced ascorbateglutathione cycle enzyme activities, and proline improves salt tolerance more than glycinebetaine in tobacco Bright Yellow-2 suspensioncultured cells. Journal of Plant Physiology, vol. 164, no. 11, pp. 1457-1468. http://dx.doi.org/10.1016/j.jplph.2006.10.004. PMid:17223225.

HU, L., HU, T., ZHANG, X., PANG, H. and FU, J., 2012. Exogenous glycine betaine ameliorates the adverse effect of salt stress on perennial ryegrass. Journal of the American Society for Horticultural Science, vol. 137, no. 1, pp. 38-46. http://dx.doi. org/10.21273/JASHS.137.1.38.

HUANG, S., ZUO, T. and NI, W., 2020. Important roles of glycinebetaine in stabilizing the structure and function of the photosystem II complex under abiotic stresses. Planta, vol. 251, no. 2, pp. 36. http://dx.doi.org/10.1007/s00425-019-03330-z. PMid:31903497.

ISLAM, S., PARREY, Z.A., SHAH, S.H. and MOHAMMAD, F., 2021. Glycine betaine mediated changes in growth, photosynthetic efficiency, antioxidant system, yield and quality of mustard. Scientia Horticulturae, vol. 285, pp. 110170. http://dx.doi. org/10.1016/j.scienta.2021.110170.

JACKSON, M.L., 1978. Soil chemical analysis. New Delhi: Fall Indian Private.

JAIN, R., KATARE, N., KUMAR, V., AMIT KUMAR, S., SWATI, G. and SHROTRI, C.K., 2012. In vitro antibacterial potential of different extracts of Tagetes erecta and Tagetes patula. Journal of Natural Sciences Research, vol. 2, pp. 84-90.

JOUSHAN, Z., SODEIZADEH, H., ARDAKANI, M.A.H., BIOUKI, R.Y. and KHAJAHHOSSEINI, S., 2020. Investigating the effect of foliar application of glycine betaine on some quantitative and qualitative characteristics of mint (Mentha spicata L.) under salinity stress. Plant Productions, vol. 43, no. 2, pp. 267-280.

KAUSAR, N., NAWAZ, K.H., HUSSAIN, K.H., BHATTI, K.H.H., SIDDIQI, E.H. and TALLA, A., 2014. Effect of exogenous applications of GlyBet on growth and gaseous exchange attributes of two maize (Zea mays L.) cultivars under saline conditions. World Applied Sciences Journal, vol. 29, no. 12, pp. 1559-1565.

KIM, N.S., KIM, J.K., SATHASIVAM, R., PARK, H.W., NGUYEN, B.V., KIM, M.C., CUONG, D.M., CHUNG, Y.S. and PARK, S.U., 2021. Impact of betaine under salinity on accumulation of phenolic compounds in safflower (Carthamus tinctorius L.) sprouts.
Natural Product Communications, vol. 16, no. 5, pp. 1-9. http:// dx.doi.org/10.1177/1934578X211015090.

LIANG, C., ZHANG, X.Y., LUO, Y., WANG, G.P., ZOU, Q. and WANG, W., 2009. Overaccumulation of glycine betaine alleviates the negative effects of salt stress in wheat. Russian Journal of Plant Physiology: a Comprehensive Russian Journal on Modern Phytophysiology, vol. 56, no. 3, pp. 370-376. http://dx.doi. org/10.1134/S1021443709030108.

LICHTENTHALER, H.K., 1987. Chlorophylls and carotenoids: pigments of photosynthetic biomembranes. Methods in Enzymology, vol. 148, pp. 350-382. http://dx.doi.org/10.1016/00766879(87)48036-1.

MANSOUR, M.M.F. and ALI, E.F., 2017. Glycinebetaine in saline conditions: an assessment of the current state of knowledge. Acta Physiologiae Plantarum, vol. 39, no. 2, pp. 56. http://dx.doi. org/10.1007/s11738-017-2357-1.

MANSOUR, M.M.F. and SALAMA, K.H.A., 2019. Cellular mechanisms of plant salt tolerance. In: B. GIRI and A. VARMA, eds. Microorganisms in saline environment: strategies and functions. Switzerland: Springer, pp. 169-210. http://dx.doi. org/10.1007/978-3-030-18975-4_8.

MCDONALD, S., PRENZLER, P.D., ANTOLOVICH, M. and ROBARDS, K., 2001. Phenolic content and antioxidant activity of olive extracts. Food Chemistry, vol. 73, no. 1, pp. 73-84. http://dx.doi. org/10.1016/S0308-8146(00)00288-0.

MLCEK, J. and ROP, O., 2011. Fresh edible flowers of ornamental plants: a new source of nutraceutical foods. Trends in Food Science E Technology, vol. 22, no. 10, pp. 561-569. http://dx.doi. org/10.1016/j.tifs.2011.04.006.

MUNHOZ, V.M., LONGHINI, R., SOUZA, J.R.P., ZEQUI, J.A.C., MELLO, E.V.S.L., LOPES, G.C. and MELLO, J.C.P., 2014. Extraction of flavonoids from Tagetes patula: process optimization and screening for biological activity. Revista Brasileira de Farmacognosia, vol. 24, no. 5, pp. 576-583. http://dx.doi. org/10.1016/j.bjp.2014.10.001.

NAHAR, K., HASANUZZAMAN, M. and FUJITA, M., 2016. Roles of osmolytes in plant adaptation to drought and salinity. In: N. IQBAL, R. NAZAR and N.A. KHAN, eds. Osmolytes and plants acclimation to changing environment: emerging omics technologies. India: Springer, pp. 37-68. http://dx.doi.org/10.1007/978-81322-2616-1_4.

O'NEAL, M.E., LANDIS, D.A. and ISAACS, R., 2002. An inexpensive accurate method for measuring leaf area and defoliation through digital image analysis. Journal of Economic Entomology, vol. 95, no. 6, pp. 1190-1194. http://dx.doi.org/10.1603/0022-049395.6.1190. PMid:12539831.

PARVIN, K., AHAMED, K.U., ISLAM, M.M. and HAQUE, M.N., 2015. Response of tomato plant under salt stress: role of exogenous calcium. Journal of Plant Sciences, vol. 10, no. 6, pp. 222-233. http://dx.doi.org/10.3923/jps.2015.222.233.

RIAZ, A., YOUNIS, A., TAJ, A.R., KARIM, A., TARIQ U., MUNIR, S. and RIAZ, S., 2013. Effect of drought stress on growth and flowering of mari- gold (Tagetes erecta L.). Pakistan Journal of Botany, vol. 45, no. S1, pp. 123-131.

SADIQUE, S., ALI, M.M., USMAN, M., UL-HASAN, M., YOUSEF, A.F., ADNAN, M., GULL, S. and NICOLA, S., 2021. Effect of foliar supplied PGRs on flower growth and antioxidant activity of African marigold (Tagetes erecta L.). Horticulturae, vol. 7, no. 10, pp. 378. http://dx.doi.org/10.3390/horticulturae7100378.

SAIRAM, R.K., DESHMUKH, P.S. and SHUKLA, D.S., 1997. Tolerance to drought and temperature stress in relation to increased antioxidant enzyme activity in wheat. Journal Agronomy 
E Crop Science, vol. 178, no. 3, pp. 171-177. http://dx.doi. org/10.1111/j.1439-037X.1997.tb00486.X.

SAXENA, S.C., KAUR, H., VERMA, P., PETLA, B.P., ANDUGULA, V.R. and MAJEE, M., 2013. Osmoprotectants: potential for crop improvement under adverse conditions. In: N. TUTEJA, and S.S. GILL, eds. Plant acclimation to environmental stress. New York: Springer Science+Business Media, pp. 197-232. http:// dx.doi.org/10.1007/978-1-4614-5001-6_9.

SHABALA, S.N., SHABALA, L., MARTYNENKO, A.I., BABOURINA, O.K. and NEWMAN, I.A., 1998. Salinity effect on bioelectric activity, growth, $\mathrm{Na}^{+}$accumulation and chlorophyll fluorescence of maize leaves: a comparative survey and prospects for screening. Australian Journal of Plant Physiology, vol. 25, pp. 609-616.

SHANNON, L., KAY, E. and LEW, J., 1966. Peroxidase isozymes from horseradish roots. I. Isolation and physical properties. The Journal of Biological Chemistry, vol. 241, no. 9, pp. 2166-2172. http:// dx.doi.org/10.1016/S0021-9258(18)96680-9. PMid:5946638.

ŠIVEL, M., KRÁČMAR, S., FIŠERA, M., KLEJDUS, B. and KUBÁŇ, V., 2014. Lutein content in Marigold Flower (Tagetes erecta L.) concentrates used for production of food supplements. Czech Journal of Food Sciences, vol. 32, no. 6, pp. 521-525. http:// dx.doi.org/10.17221/104/2014-CJFS.

SMIATEK, J., KUMAR, R.H., RUBNER, O., GALLA, H.J. and HEUER, A., 2012. Properties of compatible solutes in aqueous solution. Biophysical Chemistry, vol. 160, no. 1, pp. 62-68. http://dx.doi. org/10.1016/j.bpc.2011.09.007. PMid:22014723.

SUZUKI, N., BASSIL, E., HAMILTON, J.S., INUPAKUTIKA, M.A., ZANDALINAS, S.I., TRIPATHY, D., LUO, Y., DION, E., FUKUI, G., KUMAZAKI, A., NAKANO, R., RIVERO, R.M., VERBECK, G.F., AZAD, R.K., BLUMWALD, E. and MITTLER, R., 2016. ABA Is required for plant acclimation to a combination of salt and heat stress. PLOS One, vol. 11, no. 1, e0147625. http://dx.doi.org/10.1371/journal. pone.0147625. PMid:26824246.
TIAN, F., WANG, W., LIANG, C., WANG, X., WANG, G. and WANG, W., 2017. Over accumulation of glycine betaine makes the function of the thylakoid membrane better in wheat under salt stress. The Crop Journal, vol. 5, no. 1, pp. 73-82. http://dx.doi. org/10.1016/j.cj.2016.05.008.

TOKARZ, B., WÓJTOWICZ, T., MAKOWSKI, W., JĘDRZEJCZYK, R.J.J. and TOKARZ, K.M., 2020. What is the difference between the response of Grass Pea (Lathyrus sativus L.) to salinity and drought stress? A physiological study. Agronomy (Basel), vol. 10, no. 6, pp. 833. http://dx.doi.org/10.3390/agronomy 10060833.

VALDEZ-AGUILAR, L.A., GRIEVE, C.M., POSS, J. and MELLANO, M.A., 2009. Hypersensitivity of Ranunculus asiaticus to salinity and alkalinity in irrigation water in sand cultures. HortScience, vol. 44, no. 1, pp. 138-144. http://dx.doi.org/10.21273/HORTSCI.44.1.138.

VERSLUES, P.E., AGARWAL, M., KATIYAR-AGARWAL, S., ZHU, J. and ZHU, J.K., 2006. Methods and concepts in quantifying resistance to drought, salt and freezing, abiotic stresses that affect plant water status. The Plant Journal, vol. 45, no. 4, pp. 523-539. http:// dx.doi.org/10.1111/j.1365-313X.2005.02593.x. PMid:16441347.

WANI, S.H., SINGH, N.B., HARIBHUSHAN, A. and MIR, J.I., 2013. Compatible solute engineering in plants for abiotic stress tolerance-role of glycine betaine. Current Genomics, vol. 14, no. 3, pp. 157-165. http://dx.doi.org/10.2174/1389202911314 030001. PMid:24179438.

WEATHERLEY, P.E., 1950. Studies in the water relations of the cotton plant.1. The field measurements of water deficit in leaves. The New Phytologist, vol. 49, no. 1, pp. 8. http://dx.doi. org/10.1111/j.1469-8137.1950.tb05146.x.

WEI, D., ZHANG, W., WANG, C., MENG, Q., LI, G., CHEN, T.H.H. and YANG, X., 2017. Genetic engineering of the biosynthesis of glycinebetaine leads to alleviate salt-induced potassium efflux and enhances salt tolerance in tomato plants. Plant Science, vol. 257, pp. 74-83. http://dx.doi.org/10.1016/j.plantsci.2017.01.012. PMid:28224920. 